\title{
Pengaruh Kepemilikan Institusional, Kepemilikan Manajerial, dan Kepemilikan Asing Pada Pengungkapan Corporate Social Responsibility
}

\author{
Patrisia Adiputri Singal1 \\ Fakultas Ekonomi dan Bisnis \\ Universitas Udayana, Indonesia. \\ Email: adiputrianggie@gmail.com
}

\author{
I Nym Wijana Asmara Putra2 \\ Fakultas Ekonomi dan Bisnis \\ Universitas Udayana, Indonesia.
}

\begin{abstract}
ABSTRAK
Salah satu faktor corporate governance yang berpengaruh atas pelaksanaan CSR adalah struktur kepemilikan.Timbulnya struktur kepemilikan perusahaan akibat dari adanya perbandingan jumlah pemilik saham dalam perusahaan. Tujuan penelitian ini untuk mengetahui pengaruh kepemilikan institusional, kepemilikan manajerial, dan kepemilikan asing pada pengungkapan corporate social responsibility (CSR). Penelitian ini dilakukan di Bursa Efek Indonesia periode 2013-2017. Sampel penelitian ini adalah perusahaan Infrastruktur, Utilitas, dan Transportasi sebanyak 40 sampel dengan menggunakan purposive random sampling, dimana sampel yang diambil berdasarkan kriteria-kriteria tertentu. Pengumpulan data penelitian ini menggunakan data sekunder. Teknik analisis yang dipakai adalah analisis regresi linier berganda. Hasil penelitian ini menunjukkan bahwa kepemilikan institusional dan kepemilikan manajerial berpengaruh positif pada CSR, sedangkan kepemilikan asing berpengaruh negative tak signifikan pada pengungkapan CSR.
\end{abstract}

Kata Kunci : Kepemilikan Institusional; Kepemilikan Manajerial; Kepemilikan Asing; Pengungkapan Corporate Social Responsibility.

Effects of Institutional Ownership, Managerial Ownership, and Foreign Ownership on Corporate Social Responsibility Disclosures

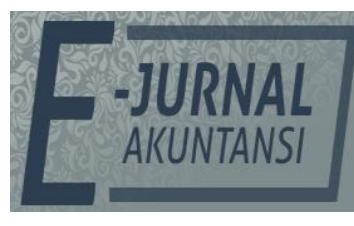

E-JA

e-Jurnal Akuntansi e-ISSN 2302-8556

Vol.298 No. 1

Denpasar, Oktober

2019

Hal. $468-484$

Artikel masuk:

13 Juni 2019

Tanggal diterima:

10 Oktober 2019

\section{ABSTRACT}

One of the factors of corporate governance that influence the implementation of CSR is the ownership structure. The emergence of corporate ownership structures results from a comparison of the number of shareholders in the company. The purpose of this study was to determine the effect of institutional ownership, managerial ownership, and foreign ownership on disclosure of corporate social responsibility (CSR). This research was conducted on the Indonesia Stock Exchange in the period 2013-2017. The sample of this research was 40 Infrastructure, Utilities and Transportation companies using purposive random sampling, where samples were taken based on certain criteria. Data collection of this study uses secondary data. The analysis technique used is the Analysis of Multiple Linear Regression. The results of this study indicate that institutional ownership and managerial ownership have a positive effect on CSR, while foreign ownership has no significant negative effect on disclosure of CSR.

Keywords: Institutional Ownership; Managerial Ownership; Foreign Ownership; Disclosure Of Corporate Social Responsibility. 


\section{PENDAHULUAN}

Semakin berkembangnya dunia bisnis dan semakin ketatnya persaingan dalam dunia bisnis menyebabkan persaingan yang ketat antara perusahaan serta kerusakan lingkungan akibat aktivitas bisnis pun meningkat, karena penggunaan sumberdaya yang sangat berlebihan demi meningkatkan laba perusahaan, dimana disisi lain perusahaan juga harus memperhatikan lingkungan sekitar. Seperti yang tercantum dalam Undang-Undang No. 40 Tahun 2007 tentang Perseroan Terbatas (pasal 74 ayat 1a) mewajibkan perusahaan yang kegiatan usahanya dibidang dan/atau berkaitan dengan sumber daya alam untuk melakukan kegiatan CSR. Pelaporan perusahaan dalam aspek ekonomi, lingkungan hidup, dan sosial (CSR disclosure) akan mempertinggi citra perusahaan di mata masyarakat dan meningkatkan kesempatan untuk bertahan (Suhardjanto \& Nugraheni, 2012). Hal tersebut menunjukan bahwa, dibutuhkannya keselarasan atau keseimbangan antara perusahaan dengan lingkungan sosial dimana perusahaan tersebut berada. Perusahaan dituntut untuk memperhatikan lingkungan sosialnya, karena dengan melakukan berbagai macam kegiatan yang berkaitan dengan lingkungan sosial, akan membuat perusahaan terlihat baik dimata masyarakat (Amran \& Devi, 2012).

Keberlanjutan perusahaan akan terjamin apabila orientasi perusahaan bergeser dari yang semula hanya bertitik tolak pada ukuran kinerja ekonomi, kini juga harus bertitik tolak pada keseimbangan lingkungan dan masyarakat dengan memperhatikan berbagai dampak sosial (Hadi, 2002).

Suatu perusahaan mempunyai beberapa kewajiban yang harus dipenuhi, kewajiban tersebut tidak hanya kepada pemegang saham namun juga kewajiban terhadap pihak lain termasuk masyarakat dan lingkungan sekitar (Mahoney \& Roberts, 2007). Seperti yang tercantum dalam Undang- Undang No. 25 Tahun 2007 tentangn Penanaman Modal (pasal 15) mewajibkan penanam modal melaksanakan tata kelola perusahaan yang baik dan melaksanakan tanggungjawab sosial perusahaan. Serta Undang-Undang No. 25 Tahun 2007 Pasal 17 menyatakan penanam modal yang mengusahakan sumber daya alam yang tidak terbarukan wajib mengalokasikan dana secara bertahap untuk pemulihan lokasi yang memenuhi standar kelayakan lingkungan hidup, yang pelaksanaannya diatur sesuai dengan ketentuan peraturan perundangundangan. Pemberlakuan Undang-Undang tersebut mendorong perusahaan untuk bertanggung jawab terhadap lingkungan sosial.

Saat ini sudah banyak perusahaan yang sadar akan hal tersebut sehingga sudah banyak pula perusahaan yang melakukan kegiatan Corporate Social Responsibility (CSR) sebagai bentuk pertanggungjawaban terhadap lingkungan sekitar (WCBSD, 2011). Pengungkapan tanggung jawab sosial merupakan salah satu media yang digunakan untuk memperlihatkan kepedulian perusahaan terhadap masyarakat di sekitarnya (Wakidi \& Siregar, 2011). Selain itu, untuk mengurangi dampak negatif aktivitas perusahaan terhadap lingkungan sekitar, maka perusahaan menerapkan program Corporate Social Responsibility (CSR). Dimana CSR merupakan suatu upaya tanggung jawab perusahaan atau organisasi atas dampak yang ditimbulkan dari keputusan dan aktivitas yang telah diambil oleh perusahaan atau organisasi tersebut, dimana dampaknya akan 
dirasakan oleh pihak-pihak terkait, termasuk masyarakat dan lingkungan (Morck et al., 1988). CSR seringkali dianggap inti dari etika bisnis, yang berarti perusahaan tidak hanya memiliki kewajiban ekonomi yang legal, tetapi juga memiliki kewajiban terhadap pihak lain yang berkepentingan (Greening \& Turban, 1997).

Perusahaan yang melakukan aktivitas CSR secara berkala, tentunya memberikan kesan yang positif bagi perusahaan dalam jangka panjang dimata masyarakat, konsumen maupun investor. Dalam hal ini, perusahaan dapat meningkatkan kepercayaan masyarakat terhadap produk maupun jasa yang dijual perusahaan, sehingga reputasi perusahaan pun meningkat dan memicu masyarakat untuk membeli produk perusahaan (Waddock \& Graves, 1997). Hal ini juga akan menarik investor untuk menanamkan modalnya di perusahaan, sehingga tercipta keberlanjutan perusahaan. Seperti yang kita ketahui pelaksanaan aktivitas CSR tidak bisa terlepas dari penerapan corporate governance. Pengungkapan pertanggungjawaban sosial dalam laporan tahunan perusahaan merupakan bentuk dari transparansi kinerja perusahaan kepada publik sesuai dengan prinsip corporate governance.

Menurut Pedoman Umum Forum for Corporate Governance in Indonesia atau disingkat FCGI (2002) menyatakan bahwa tujuan pelaksanaan corporate governance adalah mendorong timbulnya kesadaran dan tanggung jawab perusahaan pada masyarakat dan lingkungan sekitarnya. Salah satu faktor corporate governance yang berpengaruh atas pelaksanaan CSR adalah struktur kepemilikan. Timbulnya struktur kepemilikan perusahaan akibat dari adanya perbandingan jumlah pemilik saham dalam perusahaan. Sebuah perusahaan dapat dimiiliki oleh seseorang atau individual, masyarakat luas, pemerintah, pihak asing, serta orang dalam perusahaan tersebut (manajerial). Perbedaan dalam proporsi saham yang dimiliki investor dapat mempengaruhi tingkat kelengkapan pengungkapan oleh perusahaan.

Struktur kepemilikan perusahaan timbul akibat adanya perbandingan jumlah pemilik saham dalam perusahaan. Sebuah perusahaan dapat dimiliki oleh seseorang secara individu, masyarakat luas, pemerintah, pihak asing, maupun orang dalam perusahaan tersebut (manajerial). Perbedaaan dalam proporsi saham yang dimiliki oleh investor dapat mempengaruhi tingkat kelengkapan pengungkapan oleh perusahaan. Semakin banyak pihak yang butuh informasi tentang perusahaan, maka semakin detail pula pengungkapan yang dilakukan oleh perusahaan.

Kepemilikan Institusional dan kepemilikan manajerial merupakan dua mekanisme corporate governance utama yang membantu mengatasi masalah keagenan. Kepemilikan manajerial merupakan pemegang saham dari pihak manajemen yaitu dewan direksi dan dewan komisaris yang secara aktif ikut dalam pengambilan keputusan (Wahidawati, 2002). Seiring meningkatnya kepemilikan manajerial akan menyelaraskan kepentingan manajer dengan kepentingan pemegang saham, sehingga terdapat insentif bagi manajer untuk memaksimalkan nilai perusahaan ketika kepemilikan manajerialnya meningkat (Jensen \& Meckling, 1976).

Kepemilikan saham oleh manajer akan mendorong penyatuan kepentingan antara prinsipal dan agen serta dapat meningkatkan kinerja 
perusahaan (Crutchley \& Hansen, 1989). Kepemilikan saham manajerial akan mendorong manajer untuk berhati-hati dalam mengambil keputusan karena mereka ikut merasakan secara langsung manfaat dari keputusan yang diambil dan ikut menanggung kerugian dari konsekuensi dari pengambilan keputusan yang salah. Kepemilikan saham oleh manajemen akan membantu mengatasi masalah agensi karena semakin banyak saham yang dimiliki oleh manajemen maka mereka akan semakin termotivasi untuk bekerja lebih giat dan fokus dalam meningkatkan nilai perusahaan (Wati, 2012). Hal ini berarti konflik kepentingan dapat berkurang, hal ini disebabkan karena manajemen akan menyelaraskan kepentingan manajemen dengan kepentingan perusahaan, salah satu caranya adalah dengan melakukan praktik dan pengungkapan CSR (Isa \& Muhammad, 2015).

Kepemilikan Institusional memiliki arti penting dalam memonitor manajemen. Kepemilkan institusional yang besar (lebih dari 5\%) mengindikasikan kemampuannya untuk memonitor manajemen. Adanya kepemilikan oleh institusional akan mendorong pengawasan yang lebih optimal. Semakin besar kepemilikan institusional maka semakin efisien pemanfaatan aktiva perusahaan dan diharapkan juga dapat bertindak sebagai pencegah terhadap kecurangan yang dilakukan oleh manajemen (Wati, 2012). Hal ini berarti kepemilikan institusional dapat mendorong perusahaan untuk melakukan pengungkapan tanggung jawab sosial.

Kepemilikan Asing merupakan porsi outstanding share yang dimiliki oleh investor atau pemodal asing yakni perusahaan yang dimiliki oleh perorangan, badan hukum, pemerintah yang berstatus berada diluar negeri terhadap seluruh jumlah modal saham yang beredar (Yoantha, 2015). Perusahaan asing mendapat pelatihan yang lebih baik dalam bidang akuntansi dari perusahaan induk di luar negeri, perusahaan asing mungkin memiliki sistem informasi yang lebih efisien untuk memenuhi kebutuhan internal dan perusahaan induk serta kemungkinan permintaan yang lebih besar pada perusahaan berbasis asing dari pelanggan, pemasok, dan masyarakat umum (Hadi, 2002).

Kepemilikan asing dalam perusahaan merupakan pihak yang dianggap concern terhadap tanggung jawab sosial perusahaan (Machmud \& Djakman, 2008). Seperti diketahui negara-negara di Amerika dan Eropa sangat memperhatikan isu sosial misalnya hak asasi manusia, pendidikan, tenaga kerja, dan lingkungan seperti efek rumah kaca, pembalakan liar, serta pencemaran air (Machmud \& Djakman, 2008). Maka dari itu kepemilikan asing dianggap dapat memicu perusahaan untuk lebih memperhatikan lingkungan sosial dan diharapkan dapat memotivasi perusahaan untuk melakukan pengungkapan CSR.

Penelitian terdahulu menunjukkan bahwa kepemilikan manajerial berpengaruh positif dalam hubungan antara kepemilikan saham manajerial terhadap luas pengungkapan CSR (Abdullah \& Nasir, 2004). Hal senada juga diungkapkan oleh peneliti terdahulu yang mengungkapkan bahwa kepemilikan saham manajerial berpengaruh terhadap luas pengungkapan CSR di Indonesia (Rizky \& Yuyetta, 2015). Hasil penelitian sebelumnya yang telah dilakukan oleh Roshim et al., (2009) yang menemukan bahwa kepemilikan saham manajerial 
tidak berpengaruh terhadap pengungkapan CSR. Penelitian serupa juga dikemukakan oleh penelitian Huafang (2007) yang membuktikan bahwa kepemilikan manajemen tidak berpengaruh terhadap CSR.

Penelitian sebelumnya menemukan bahwa kepemilikan institusional dan kepemilikan asing tidak berpengaruh secara signifikan terhadap pengungkapan CSR, sedangkan kepemilikan manajerial berpengaruh signifikan terhadap pengungkapan CSR (Edison, 2017). Bukti empiris bahwa pencapaian dari aspek sosial antara perusahaan nasional dengan perusahaan multinasional adalah sama. Sedangkan dari aspek lingkungan, pencapaian perusahaan multinasional yang ada di Indonesia lebih baik daripada perusahaan nasional (Fauzi \& Sebelas, 2008). Namun, secara teoritis semakin tinggi kepemilikan institusional, kepemilikan manajerial, dan kepemilikan asing menjadikan pengawasan yang lebih ketat terhadap manajemen perusahaan untuk melakukan dan mengungkapkan kegiatan sosial perusahaan.

Berdasarkan hasil penelitian-penelitian sebelumnya yang tidak konsisten mendorong peneliti untuk menguji kembali variabel kepemilikan institusional, kepemilikan manajerial, dan kepemilikan asing terhadap pengungkapan pertanggung jawaban sosial perusahaan, karena masih banyak hasil penelitian yang berbeda-beda. Penelitian ini meneliti dengan periode yang berbeda yaitu 2013-2017. Terdapat 40 sampel dalam penelitian ini. Penelitian ini meneliti kepemilikan institusional, kepemilikan manajerial, dan kepemilikan asing pada perusahaan Infrastruktur, Utilitas, dan Transportasi. Sektor infrastruktur, Utilitas, dan Transportasi merupakan perusahaan-perusahaan yang perkembangannya sangat baik dan pesat di Indonesia. Maka dari itu peneliti tertarik meneliti kepemilikan institusional, kepemilikan manajerial, dan kepemilikan asing pada perusahaan sektor infrastruktur, utilitas, dan transportasi.

Ketentuan mengenai kegiatan CSR di Indonesia diatur dalam UndangUndang No. 25 Tahun 2007 tentang Penanaman Modal dan Undang-Undang No. 40 Tahun 2007 tentang Perseroan Terbatas yang mewajibkan perseroan atau penanam modal untuk melaksanakan tanggung jawab sosial perusahaan. Ketentuan ini bertujuan untuk mendukung terjalinnya hubungan yang serasi dan seimbang antara perusahaan dengan lingkungan sesuai dengan nilai, norma, dan budaya masyarakat setempat. Pengaturan CSR juga bertujuan untuk mewujudkan pembangunan ekonomi berkelanjutan guna meningkatkan kualitas kehidupan dan lingkungannya (Wahyudi \& Busya, 2008).

Menurut Global Compact (2002) pemahaman CSR mencakup 3P yaitu profit, people, planet. Konsep ini memuat pengertian bahwa bisnis tidak hanya sekedar mencari keuntungan (profit) melainkan juga kesejahteraan orang (people) dan menjamin keberlangsungan hidup (planet) (Dahlia \& Siregar, 2008). Maka dari itu diharapkan perusahaan-perusahaan, terutama perusahaan yang menjalankan kegiatan bisnisnya menggunakan sumber daya alam agar lebih memperhatikan lingkungan dan dapat mempertanggungjawabkan kegiatan usahanya dengan melakukan kegiatan Cororate Social Responsibility. Selain untuk menjaga lingkungan melakukan kegiatan CSR juga sebagai salah satu cara keberlansungan dari perusahaan itu sendiri, karena perusahaan akan dikenal dengan citra yang baik oleh masyarakat dan akan lebih diakui keberadaannya. 
Pengungkapan informasi CSR merupakan salah satu cara perusahaan membangun, mempertahankan, dan meligitimasi kontribusi perusahaan dari sisi ekonomi dan politis (Suparjan \& Mulya, 2012).

Berdasarkan UU No.40 pasal 66 ayat 2 tahun 2007, pengungkapan pertanggungjawaban sosial wajib dimuat dalam annual report. Pengungkapan sosial dalam tanggung jawab perusahaan sangat perlu dilakukan, karena dengan melakukan pengungkapan sosial perusahaan memperoleh nilai tambah dari kontribusi masyarakat di sekitar perusahaan termasuk dari penggunaan sumbersumber sosial (social resources). Jika aktivitas perusahaan menyebabkan kerusakan sumber-sumber sosial maka dapat timbul adanya biaya sosial yang harus ditanggung oleh masyarakat, sedangkan apabila perusahaan meningkatkan mutu social resources maka akan menimbulkan social benefit (manfaat sosial).

Kepemilikan institusional adalah kepemilikan saham yang dimiliki oleh institusi atau lembaga, seperti perusahaan asuransi, bank, perusahaan investasi, aset managemen dan kepemilikan institusi lainnya. Kepemilikan institusional merupakan pemegang saham terbesar sehingga merupakan sarana untuk memonitor manajemen (Machmud \& Djakman, 2008). Karena memiliki saham terbesar, investor institusional berhak untuk meminta manajemen perusahaan untuk mengungkapan laporan tahunan secara transparan dengan cara mengungkapkan informasi sosialnya sebagai bentuk tanggung jawab kepada pemegang saham dan juga masyarakat untuk memperoleh legitimasi dan menaikkan nilai perusahaan melalui mekanisme pasar modal sehingga mempengaruhi harga saham perusahaan.

Salah satu cara untuk mengurangi agency cost adalah dengan meningkatkan kepemilikan institusional yang berfungsi untuk mengawasi agen (Jensen \& Meckling, 1976). Degan kata lain, akan mendorong pengawasan yang optimal terhadap kinerja manajemen. Hal ini menunjukkan bahwa peningkatan presentase kepemilikan institusional dapat menurunkan prosentase kepemilikan manajerial karena kepemilikan manajerial dan kepemilikan institusional bersifat saling menggantikan sebagai fungsi monitoring.

Kepemilikan manajerial adalah pemegang saham dari pihak manajemen (dewan direksi dan dewan komisaris) yang secara aktif ikut dalam pengambilan keputusan (Wahidawati, 2002). Kepemilikan manajerial dapat diukur dengan menggunakan rasio antara jumlah saham yang dimiliki manajer atau dewan direksi ataupun dewan komisaris terhadap total saham yang beredar (Rustendi \& Jimmi, 2008). Kepemilikan saham oleh manajer akan mendorong penyatuan kepentingan antara prinsipal dengan agen sehingga agen bertindak sesuai dengan keinginan pemegang saham dan dapat meningkatkan kinerja perusahaan (Crutchley \& Hansen, 1989). Seiring meningkatnya kepemilikan manajerial akan menyelaraskan kepentingan manajer dengan kepentingan pemegang saham (Jensen \& Meckling, 1976). Kepemilikan manajerial dapat mengurangi masalah agensi karena kinerja manajer akan lebih baik seiring dengan peningkatan kepemilikan saham dalam perusahaan tersebut. Manajer akan berusaha dengan giat memperbaiki kinerja perusahaan, yang pada akhirnya akan meningkatkan nilai perusahaan. 
Semakin besar kepemilikan manjemen dalam perusahaan maka manajemen akan cenderung untuk berusaha untuk meningkatkan kinerjanya untuk kepentingan pemegang saham dan untuk kepentingannya sendiri (Siallagan \& Machfoedz, 2006).

Berdasarkan teori keagenan, perbedaan kepentingan antara manajer dan pemegang saham ini mengakibatkan timbulnya konflik yang biasa disebut dengan agency conflict. Konflik kepentingan antara manajer dan pemegang saham menjadi semakin besar ketika kepemilikan manajerial didalam perusahaan semakin kecil. Sebaliknya, semakin besar kepemilikan manajer didalam perusahaan maka manajer perusahaan akan meningkatkan citra perusahaan dengan mengungkapkan pertanggungjawaban sosial perusahaan (Gray et al., 1995).

Kepemilikan Institusional adalah kepemilikan saham perusahaan yang dimiliki oleh suatu institusi atau badan (lembaga). Tingkat kepemilikan institusional yang tinggi akan menimbulkan usaha pengawasan yang lebih besar oleh pihak investor institusional sehingga dapat menghalangi perilaku opportunistic manajer (Machmud \& Djakman, 2008).

Kepemilikan institusional dapat dijadikan sebagai upaya untuk mengurangi masalah keagenan dengan meningkatkan proses monitoring (Mursalim, 2007). Pemegang saham institusional juga memiliki opportunity, resources, dan expertis untuk menganalisis kinerja dan tindakan manajemen. Investor institusional sebagai pemilik sangat berkepentingan untuk membangun reputasi perusahaan. Perusahaan dengan kepemilikan institusional yang besar mengindikasikan kemampuannya untuk memonitor manajemen. Semakin besar kepemilikan institusional maka semakin efisien pemanfaatan aktiva perusahaan yang diharapkan juga dapat bertindak sebagai pencegahan terhadap peemborosan yang dilakukan oleh manajemen perusahaan tersebut (Faisal, 2005).

Hasil penelitian Reni \& Anggraini (2006) menyatakan kepemilikan institusional berpengaruh pada pengungkapan CSR. Hasil penelitiannya menunjukkan semakin besar kepemilikan institusional dalam perusahaan maka tekanan terhadap manajemen perusahaan untuk mengungkapkan tanggung jawab sosial pun semakin besar.

Perusahaan dengan kepemilikan institusional yang besar lebih mampu untuk memonitor kinerja manajemen. Investor institusional memiliki power dan experience serta bertanggung jawab dalam menerapkan prinsip corporate governance untuk melindungi hak dan kepentingan seluruh pemegang saham sehingga mereka menuntut perusahaan untuk melakukan komunikasi secara transparan (Matoussi \& Chakroun, 2008). Dengan demikian, kepemilikan institusional dapat mengingkatkan kualitas dan kuantitas pengungkapan sukarela. Hal ini berarti kepemilikan institusional dapat mendorong perusahaan untuk meningkatkan pengungkapan CSR. CSR biasanya dipandang sebagai alat untuk meningkatkan reputasi perusahaan dan menimbulkan goodwill diantara pelanggan (Chernev \& Blair, 2015). Banyak penelitan sebelumnya yang menunjukkan bahwa pengungkapan pertanggungjawaban sosial perusahaan meningkat tiap tahun. Banyak perusahaan yang semakin menyadari pentingnya 
program CSR sebagai salah satu bagian dari strategi perusahaan dan mendapatkan legitimasi oleh masyarakat (Permanasari, 2010).

Berdasarkan uraian di atas, maka hipotesis yang dapat dirumuskan adalah sebagai berikut:

$\mathrm{H}_{1}$ : Kepemilikan saham institusional berpengaruh positif pada pengungkapan CSR.

Semakin besar proporsi kepemilikan manajemen pada perusahaan, maka manajemen cenderung berusaha lebih giat untuk kepentingan pemegang saham yang tidak lain adalah dirinya sendiri.

Menurut Rawi \& Muchlish (2010) dalam penelitiannya menemukan bahwa kepemilikan manajemen berpengaruh terhadap CSR. Penelitian Abdullah \& Nasir (2004) juga menunjukkan bahwa kepemilikan manajerial berpengaruh positif dalam hubungan antara kepemilikan saham manajerial terhadap luas pengungkapan CSR. . Hal senada juga diungkapkan oleh peneliti terdahulu yang mengungkapkan bahwa kepemilikan saham manajerial berpengaruh terhadap luas pengungkapan CSR di Indonesia (Rizky \& Yuyetta, 2015). Jadi, hipotesis yang dapat disimpulkan dalam penelitian ini adalah:

$\mathrm{H}_{2}$ : Kepemilikan Manajerial berpengaruh positif pada pengungkapan CSR.

Kepemilikan saham asing adalah jumlah saham yang dimiliki oleh pihak asing (luar negeri) baik oleh individu maupun lembaga atau institusi terhadap saham perusahaan di Indonesia. Kepemilikan asing dalam perusahaan merupakan pihak yang dianggap concern terhadap pengungkapan pertanggungjawaban sosial perusahaan. Terbukti dari penelitian terdahulu yang menyatakan bahwa dari aspek lingkungan, pencapaian perusahaan multinasional yang berada di Indonesia lebih baik daripada perusahaan nasional. Tidak ada hubungan antara kinerja sosial dengan kinerja keuangan dalam perusahaan nasional. Sedangkan dalam perusahaan multinasional terdapat hubungan antara kinerja sosial dan kinerja keuangan. Berarti perusahaan dengan kepemilikan asing akan cenderung mengungkapkan pertanggungjawaban sosial yang lebih besar karena mempunyai dana yang besar untuk mendanai kegiatan sosial dan lingkungan. Hal ini menjadikan perusahaan multinasional mulai mengubah perilaku mereka dalam beroperasi demi menjaga legitimasi dan reputasi perusahaan (Fauzi \& Sebelas, 2008).

Perusahaan dengan kepemilikan saham asing biasanya lebih sering menghadapi masalah asimetri informasi dikarenakan alasan hambatan geografis dan bahasa. Oleh karena itu, perusahaan dengan kepemilikan saham asing yang besar akan terdorong untuk melaporkan atau mengungkapkan informasinya secara sukarela dan lebih luas (Huafang, 2007).

Hasil penelitian terdahulu menyatakan kepemilikan asing berpengaruh pada pengungkapan CSR. Hasil penelitiannya menunjukkan bahwa perusahaan yang memiliki kepemilikan saham asing cenderung memberikan pengungkapan yang lebih luas dibandingkan yang tidak. Hal ini disebabkan beberapa alasan. Pertama, perusahaan asing terutama dari Eropa dan Amerika lebih mengenal konsep praktik dan pengungkapan CSR. Kedua, perusahaan asing mendapatkan pelatihan yang lebih baik dalam bidang akuntansi dari perusahaan induk di luar negeri. Ketiga, perusahaan tersebut mungkin mempunyai sistem informasi yang lebih efisien untuk memenuhi kebutuhan internal dan kebutuhan perusahaan 
induk. Keempat, kemungkinan permintaan yang lebih besar pada perusahaan berbasis asing dari pelanggan, pemasok, dan masyarakat umum (Puspitasari, 2009).

Selain itu, apabila perusahaan memiliki kontrak dengan pemegang saham asing baik dalam bentuk ownership maupun trade, maka perusahaan akan lebih didukung dalam melakukan pengungkapan tanggung jawab sosial (Barkemeyer, 2007). Negara-negara asing juga cenderung lebih memperhatikan segala aktivitas yang berhubungan dengan pengungkapan CSR. Hal ini terlihat dari tingginya tingkat kepedulian perusahaan asing terhadap kasus-kasus sosial yang terjadi seperti pelanggaran HAM, tenaga kerja, dan kasus lingkungan seperti global warming, penebangan liar, serta pencemaran udara maupun air.

Berdasarkan asumsi bahwa negara-negara asing cenderung lebih memperhatikan aktivitas serta pengungkapan CSR, maka penelitian ini mengajukan hipotesis sebagai berikut:

$\mathrm{H}_{3}$ : Kepemilikan saham asing berpengaruh positif pada pengungkapan CSR.

\section{METODE PENELITIAN}

Penelitian ini dilakukan pada Bursa Efek Indonesia dengan mengakses situs www.idx.com. Alasan mendasar dipilihnya lokasi ini adalah karena data- data yang mendukung untuk penelitian ini terdapat di Bursa Efek Indonesia. Bursa Efek Indonesia merupakan sebuah pasar yang berhubungan dengan pembelian dan penjualan efek perusahaan yang sudah terdaftar di bursa itu. Bursa efek tersebut, bersama-sama dengan pasar uang merupakan sumber utama permodalan eksternal bagi perusahaan dan pemerintah. Sebuah bursa efek sering kali menjadi komponen terpenting dari sebuah pasar saham. Bursa efek Indonesia menggunakan sistem perdagangan bernama Jakarta Automated Trading System (JATS) sejak 22 mei 1995, menggantikan sistem manual yang digunakan sebelumnya.

Pengungkapan CSR merupakan proses pemberian informasi kepada kelompok yang berkepentingan tetang aktivitas perusahaan serta dampaknya terhadap sosial dan lingkungan (Mathews, 1995). CSR dihitung menggunakan rumus:

$$
\mathrm{CSRIj}=\sum \frac{X i j}{n j}
$$

Keterangan:

CSRIj : Corporate Social Responsibility Disclosure Index perusahaan $\mathrm{j}$

nj : Jumlah item untuk perusahaan $\mathrm{j}$

Xij $\quad$ : Dummy Variabel : 1 = jika item j diungkapkan; $0=$ jika item tidak diungkapkan

Kepemilikan Institusional merupakan kepemilikan saham perusahaan oleh institusi (badan) seperti yayasan, bank, perusahaan asuransi, perusahaan investasi, dana pensiun, perusahaan berbentuk perseroan dan lain sebagainya. Struktur kepemilikan institusional dapat diukur sesuai dengan proporsi kepemilikan saham yang dimiliki oleh pihak institusi atau lembaga dibagi dengan jumlah saham yang beredar Sartono (2010) dirumuskan sebagai berikut : $\frac{\text { jumlah kepemilikan saham oleh pihak institusional }}{\text { jumlah saham yang beredar }} \times 100$ 
Kepemilikan manjerial adalah persentase jumlah saham yang dimiliki manajemen dari seluruh jumlah saham perusahaan yang dikelola. Kepemilikan manajerial diukur dengan menggunakan rasio antara jumlah saham yang dimiliki oleh pihak manajerial (manajer dan dewan direksi) terhadap total saham yang beredar pada perusahaan (Sartono, 2010). Rumus menghitung kepemilikan manajerial dirumuskan sebagai berikut :

$\frac{\text { total saham yang dimiliki manajemen }}{\text { jumlah saham yang dikelola perusahaan }} \times 100 \%$.

Kepemilikan asing, yaitu saham yang dimiliki oleh kepemilikan asing dalam bentuk badan usaha asing. Kepemilikan asing dalam penelitian ini menggunakan persentase kepemilikan saham asing yang dilihat dalam laporan tahunan perusahaan untuk tahun 2013-2017. Apabila suatu perusahaan terdapat lebih dari satu pemilikan asing yang memiliki saham perusahaan, maka kepemilikan saham diukur dengan menghitung total seluruh saham yang dimiliki oleh seluruh kepemilikan asing. Dengan cara membagi jumlah saham yang dimiliki oleh pemegang saham asing dengan total jumlah saham yang beredar (Sissandhy \& Sudarno, 2014).

Populasi yang digunakan dalam penelitian ini adalah seluruh perusahaan infrastruktur, utilitas, dan transportasi yang terdaftar di BEI, terdapat 72 perusahaan infrastruktur, utilitas, dan transportasi yang terdaftar di BEI periode 2013-2017. Sampel dalam penelitian ini berjumlah 40. Sampel yang digunakan adalah seluruh perusahaan utilitas, infrastruktur, dan transportasi yang terdaftar di BEI dengan kriteria-kriteria tertentu.

Pengumpulan data dalam penelitian ini melalui laporan tahunan yang terdaftar di BEI dan melalui studi pustaka, buku-buku literatur, dan jurnal penelitian terdahulu yang berkaitan dengan penelitian yang sedang dilakukan.

Pengujian hipotesis dalam penelitian ini menggunakan metode analisis regresi berganda (Multiple Regression) untuk menguji hubungan linear antara CSR dengan variabel-variabel independen. Pengujian hipotesis dilakukan secara multivariate dengan menggunakan regresi berganda. Regresi berganda digunakan untuk menguji apakah variabel-variabel independen dalam penelitian ini yaitu kepemilikan institusional (INST), Kepemilikan Manajerial (MANJ) dan kepemilikan asing (ASING) mempengaruhi pengungkapan pertanggungjawaban sosial. Berikut merupakan persamaan regresi yang digunakan penelitian ini:

$\mathrm{Y}=\alpha+\beta 1 \mathrm{KM}+\beta 2 \mathrm{KI}+\beta 3 \mathrm{KA}+\mathrm{e}$

Keterangan:

$$
\begin{aligned}
& \mathrm{Y}=\text { Corporate Social Responsibility Index (CSRI) } \\
& \mathrm{a}=\text { konstanta } \\
& \mathrm{KM}=\text { kepemilikan manajerial } \\
& \mathrm{KI}=\text { kepemilikan institusional } \\
& \mathrm{KA}=\text { kepemilikan asing } \\
& \mathrm{e}=\text { error term, yaitu tingkat kesalahan penduga dalam penelitian }
\end{aligned}
$$

\section{HASIL DAN PEMBAHASAN}

Statistik deskriptif disajikan untuk memberikan informasi mengenai karakteristik variabel-variabel penelitian, antara lain nilai minimum, maksimum, rata-rata dan standar deviasi. 
Nilai minimum untuk Kepemilikan Institusional adalah 0,0730 dan nilai maksimum untuk Kepemilikan Institusional adalah 0,9790. Hal ini berarti bahwa dari semua perusahaan sampel, Sarana Menara Nusantara Tbk (TOWR) merupakan perusahaan dengan nilai Kepemilikan Institusional terendah. Sedangkan, perusahaan sampel dengan nilai Kepemilikan Institusional tertinggi adalah PT Tower Bersama Infrastructure Tbk (TBIG) . Nilai rata-rata Kepemilikan Institusional adalah 0,629847.

Nilai minimum untuk Kepemilikan Manajerial adalah 0,00003 dan nilai maksimum untuk Kepemilikan Manajerial adalah 0,8291. Hal ini berarti bahwa dari semua perusahaan sampel, Trans Tower Marine Tbk (TPMA) merupakan perusahaan dengan nilai Kepemilikan Manajerial terendah. Sedangkan, perusahaan sampel dengan nilai Kepemilikan Manajerial tertinggi adalah Wintermar Ofshore Marine Tbk. Nilai rata-rata Kepemilikan Manajerial adalah 0,178134 .

Nilai minimum untuk Kepemilikan Asing adalah 0,0780 dan nilai maksimum untuk Kepemilikan Asing adalah 11,7700 . Hal ini berarti bahwa dari semua perusahaan sampel, PT Indika Energy Tbk merupakan perusahaan dengan nilai Kepemilikan Asing terendah. Sedangkan, perusahaan sampel dengan nilai Kepemilikan Asing tertinggi adalah PT Trans Power Marine Tbk (TPMA) . Nilai rata-rata Kepemilikan Manajerial adalah 3,369305.

Nilai minimum untuk CSR adalah 0,2600 dan nilai maksimum untuk CSR adalah 0,8291. Hal ini berarti bahwa dari semua perusahaan sampel, Leyand International Tbk (LAPD) merupakan perusahaan dengan nilai CSR terendah. Sedangkan, perusahaan sampel dengan nilai CSR tertinggi adalah Sarana Menara Nusantara Tbk (TOWR) . Nilai rata-rata CSR adalah 0,412828.

Tabel 1. Hasil Analisis Regresi

\begin{tabular}{|c|c|c|c|c|c|c|c|c|}
\hline \multirow{3}{*}{\multicolumn{2}{|c|}{ Model }} & \multicolumn{2}{|c|}{$\begin{array}{c}\text { Unstandardized } \\
\text { Coefficients }\end{array}$} & \multirow{3}{*}{$\begin{array}{c}\text { Standardized } \\
\text { Coefficients } \\
\text { Beta } \\
\end{array}$} & \multirow[b]{3}{*}{$t$} & \multirow[b]{3}{*}{ Sig. } & \multicolumn{2}{|c|}{ Collinearity Statistics } \\
\hline & & & Std. & & & & & \\
\hline & & $B$ & Error & & & & Tolerance & VIF \\
\hline \multirow[t]{4}{*}{1} & (Constant) & . 197 & .045 & & 4.355 & .000 & & \\
\hline & $\begin{array}{l}\text { Kep. } \\
\text { Institusional }\end{array}$ & 237 & .072 & .338 & 3.290 & .002 & .859 & 1.164 \\
\hline & $\begin{array}{l}\text { Kep. } \\
\text { Manajerial }\end{array}$ & 411 & .060 & .692 & 6.878 & .000 & .893 & 1.119 \\
\hline & Kep. Asing & -.002 & .005 & -.041 & -.394 & .696 & .837 & 1.194 \\
\hline
\end{tabular}

Sumber: Data Penelitian, 2019

Berdasarkan tabel 1. dapat disusun persamaan regresi sebagai berikut:

$$
Y=0,197+0,237 X_{1}+0,411 X_{2}-0,002 X_{3}
$$

Nilai konstanta (a) sebesar 0,197, artinya bila kepemilikan institusional $\left(X_{1}\right)$, kepemilikan manajerial $\left(X_{2}\right)$ dan kepemilikan asing $\left(X_{3}\right)$ sebesar 0,197 , maka pengungkapan corporate social responsibility $(Y)$ adalah sebesar 0,197\% . $\beta_{1}=0,237$ artinya bila kepemilikan institusional $\left(\mathrm{X}_{1}\right)$ bertambah maka pengungkapan corporate social responsibility $(\mathrm{Y})$ meningkat sebesar $0,237 \%$ dengan asumsi variabel lain konstan. $\beta_{2}=0,411$ artinya kepemilikan manajerial $\left(\mathrm{X}_{2}\right)$ bertambah maka pengungkapan corporate social responsibility $(\mathrm{Y})$ akan meningkat sebesar 0,411\%. $\quad \mathrm{B}_{3}=-0,002$ artinya kepemilikan asing $\left(X_{3}\right)$ berkurang maka pengungkapan corporate social responsibility $(\mathrm{Y})$ menurun sebesar 0,002\%. Hasil 
persamaan regresi linier berganda tersebut menunjukkan arah pengaruh masingmasing koefisien variabel bebas terhadap variabel terikat yang ditunjukkan oleh masing-masing koefisien variabel bebasnya.

Uji $F$ bertujuan untuk mengetahui pengaruh variabel bebas terhadap variabel terikat. Apabila nilai signifikansi annova $<\alpha=0,05$ maka model ini dikatakan layak atau variabel independen mampu memprediksi dan menjelaskan variabel dependen. Hasil dari uji F ini akan disajikan dalam tabel 2.

Tabel 2. Hasil Kelayakan Model (Uji F)

\begin{tabular}{|c|c|c|c|c|c|c|}
\hline Model & & $\begin{array}{l}\text { Sum of } \\
\text { Squares }\end{array}$ & $d f$ & Mean Square & $F$ & Sig. \\
\hline \multirow[t]{3}{*}{1} & Regression & .014 & 3 & .005 & 2.744 & $.057(\mathrm{a})$ \\
\hline & Residual & .059 & 36 & .002 & & \\
\hline & Total & .073 & 39 & & & \\
\hline
\end{tabular}

Sumber: Data Penelitian, 2019

Berdasarkan tabel 2 di atas menunjukkan nilai $\mathrm{F}$ sebesar $0,000<$ alpha $(\mathrm{a}=$ 0,05), maka $\mathrm{H}_{0}$ ditolak dan $\mathrm{H}_{1}$ diterima. Hal ini berarti kepemilikan institusional, kepemilikan manajerial, dan kepemilikan asing berpengaruh pada pengungkapan corporate social responsibility.

Penelitian ini dilakukan untuk mengetahui apakah ada pengaruh secara parsial antara Kepemilikan Institusional, Kepemilikan Manajerial, dan Kepemilikan Asing pada Pengungkapan Corporate Social Responsibility (CSR) perusahaan Infrastruktur, Utilitas dan Transportasi yang terdaftar di BEI tahun 2013-2017. Hasil uji $\mathrm{t}$ dapat dilihat pada tabel 3.

Tabel 3. Hasil Uji Hipotesis (Uji t)

\begin{tabular}{cccc}
\hline Variabel Bebas & Hasil & Koefisien & Signifikansi \\
\hline X1 & Positif signifikan & 0,237 & 0,002 \\
X2 & Positif signifikan & 0,411 & 0,000 \\
X3 & Negatif tak signifikan & $-0,002$ & 0,696 \\
\hline
\end{tabular}

Sumber: Data Penelitian, 2019

Berdasarkan tabel 3 bahwa variabel kepemilikan institusional memiliki nilai koefisien sebesar 0, 237 dengan nilai signifikansinya adalah 0,002. Nilai ini lebih besar dari a yaitu 0,05, maka $\mathrm{H}_{0}$ ditolak dan $\mathrm{H}_{1}$ diterima sehingga kepemilikan institusional berpengaruh positif pada pengungkapan corporate social responsibility (CSR). Hasil hipotesis ini juga sesuai dengan hasil penelitian sebelumnya yaitu hasil penelitian Reni \& Anggraini (2006) menyatakan kepemilikan institusional berpengaruh pada pengungkapan CSR. Hasil penelitiannya menunjukkan semakin besar kepemilikan institusional dalam perusahaan maka tekanan terhadap manajemen perusahaan untuk mengungkapkan tanggung jawab sosial pun semakin besar.

Berdasarkan tabel 3 bahwa variabel kepemilikan manajerial memiliki nilai koefisien 0,411 dengan nilai signifikansinya adalah 0,0000 . Nilai ini lebih kecil dari dari a yaitu 0,05, maka $\mathrm{H}_{0}$ ditolak dan $\mathrm{H}_{1}$ diterima sehingga kepemilikan manajerial berpengaruh positif pada pengungkapan corporate social responsibility (CSR).

Kepemilikan manajerial yang dinilai dengan presentase kepemilikan saham oleh pihak manajer memiliki pengaruh yang signifikan, penelitian ini sesuai dengan hasil penelitian terdahulu, dimana dalam penelitiannya 
menemukan bahwa kepemilikan manajemen berpengaruh terhadap CSR (Rawi \& Muchlish, 2010). Penelitian lainnya juga menunjukkan bahwa kepemilikan manajerial berpengaruh positif dalam hubungan antara kepemilikan saham manajerial terhadap luas pengungkapan CSR (Abdullah \& Nasir, 2004). Hal senada juga diungkapkan oleh peneliti terdahulu yang mengungkapkan bahwa kepemilikan saham manajerial berpengaruh terhadap luas pengungkapan CSR di Indonesia (Rizky \& Yuyetta, 2015). Hasil penelitian sebelumnya yang dilakukan Dewi, (2015), Prakasa \& Astika (2017) dan Rahayu (2015) mendapatkan hasil bahwa kepemilikan manajerial berpengaruh positif pada pengungkapan CSR, dimana intensitas pengungkapan CSR akan meningkat seiring meningkatnya kepemilikan manajerial.

Berdasarkan tabel 3 bahwa variabel kepemilikan asing memiliki nilai koefisien -0,002 dengan nilai signifikansinya 0,696. Nilai ini lebih besar dari a yaitu 0,05, maka $\mathrm{H}_{0}$ diterima dan $\mathrm{H}_{1}$ ditolak sehingga kepemilikan asing berpengaruh negatif tak signifikan pada pengungkapan corporate social responsibility (CSR). Hasil penelitian ini juga didukung oleh penelitian sebelumnya yang menyatakan bahwa kepemilikan asing tidak berpengaruh secara signifikan terhadap pengungkapan CSR (Edison, 2017). Hal senada juga didapat dari hasil penelitian sebelumnya bahwa kepemilikan asing tidak berpengaruh pada pengungkapan CSR (Rohmah, 2015).

Penelitian sebelumnya juga mengungkapkan bahwa kepemilikan asing tidak berpengaruh pada intensitas pengungkapan CSR. Ada atau tidaknya kepemilikan asing dalam suatu perusahaan tidak berpengaruh pada pengungkapan CSR. Hal ini disebabkan karena perusahaan pertambangan termasuk dalam perusahaan high profile (Wulandari \& Sudana, 2018). Hal ini senada dengan penelitian ini perusahaan infrastruktur, utilitas,dan transportasi termasuk kategori perusahaan high profile. Menurut Hackston \& Milne (1996) perusahaan yang termasuk dalam kategori perusahaan high profile memiliki tingkat sensitivitas yang cukup tinggi terhadap lingkungan sekitarnya atau persaingan yang cukup ketat di lingkungan bisnisnya.

Berdasarkan hasil penelitian yang diperoleh, terdapat beberapa implikasi dalam penelitian ini, dimana implikasi yang pertama dalam penelitian ini yaitu variabel kepemilikan institusional berpengaruh positif pada pengungkapan corporate social responsibility. Hal ini berarti kepemilikan saham yang dimiliki pihak institusi mempengaruhi pengungkapan pertanggungjawaban perusahaan.

Implikasi yang kedua yaitu kepemilikan manajerial berpengaruh positif signifikan pada pengungkapan CSR, ini berarti bahwa kepemilikan saham yang dimiliki oleh pihak manajerial mempengaruhi pengungkapan pertanggungjawaban perusahaan. Seiring meningkatnya kepemilikan manajerial akan menyelaraskan kepentingan manajer dengan kepentingan pemegang saham (Jensen \& Meckling, 1976). Hal ini sesuai dengan teori keagenan semakin besar kepemilikan manajer didalam perusahaan maka manajer perusahaan akan meningkatkan citra perusahaan dengan mengungkapkan pertanggungjawaban sosial perusahaan (Gray et al., 1995).

Implikasi yang ketiga dalam penelitian ini yaitu, kepemilikan asing berpengaruh negatif tidak signifikan, ini berarti dalam penelitian ini kepemilikan saham oleh pihak asing tidak mempengaruhi pengungkapan CSR. Ada atau 
tidaknya kepemilikan asing dalam suatu perusahaan tidak berpengaruh pada pengungkapan CSR. Hal ini disebabkan karena perusahaan pertambangan termasuk dalam perusahaan high profile (Wulandari \& Sudana, 2018). Hal ini senada dengan penelitian ini perusahaan infrastruktur, utilitas,dan transportasi termasuk kategori perusahaan high profile.

\section{SIMPULAN}

Variabel kepemilikan institusional berpengaruh positif signifikan pada pengungkapan corporate social responsibility pada perusahaan Infrastruktur, Utilitas dan Transportasi periode 2013-2017. Variabel kepemilikan manajerial berpengaruh positif signifikan pada pengungkapan corporate social responsibility pada perusahaan Infrastruktur, Utilitas dan Transportasi periode 2013-2017. Variabel kepemilikan asing berpengaruh negatif tak signifikan pada pengungkapan corporate social responsibility pada perusahaan Infrastruktur, Utilitas dan Transportasi periode 2013-2017.

Kepada peneliti selanjutnya bisa mengembangkan indikator untuk menjelaskan luas pengungkapan corporate social responsibility karena regulasi mengenai pengungkapan CSR terus berkembang.

Peneliti selanjutnya dapat memperpanjang periode penelitian sehingga lebih terlihat bagaimana trend dari pengaruh masing-masing variabel yang diteliti terhadap pengungkapan CSR dalam jangka panjang.

\section{REFERENSI}

Abdullah, S., \& Nasir, N. (2004). Accrual management and the independence of the boards of directors and audit committees. International Journal of Economics and Management, 12(1), 1-31. Retrieved from http://journals.iium.edu.my/enmjournal/index.php/enmj/article/view/9 7

Aminu Isa, M., \& Muhammad, S. (2015). The Impact of Board Characteristics on Corporate Social Responsibility Disclosure: Evidence from Nigerian Food Product Firms. International Journal of Management Science and Business Administration, 1(12), 34-45. https://doi.org/10.18775/ijmsba.1849-56645419.2014.112.1004

Amran, A., \& Susela Devi, S. (2012). Managerial Auditing Journal The impact of government and foreign affiliate influence on corporate social reporting The case of Malaysia. Managerial Auditing Journal, 23(4), 386-404. https://doi.org/10.1108/02686900810864327

Barkemeyer, R. (2007). Legitimacy as a key driver and determinant of CSR in developing countries Legitimacy as a Key Driver and Determinant of CSR in Developing Countries Paper for the 2007 Marie Curie Summer School on Earth System Governance ,. Marie Curie Summer School on Earth System Governance, 44(June), 1-23.

Chernev, A., \& Blair, S. (2015). Doing Well by Doing Good: The Benevolent Halo of Corporate Social Responsibility. Journal of Consumer Research, 41(6), 14121425. https://doi.org/10.1086/680089

Compact, G. (2002). The UN Global Compact.

Crutchley, C. E., \& Hansen, R. S. (1989). A Test of the Agency Theory of 
Managerial Ownership, Corporate Leverage, and Corporate Dividends. Journal of Financial Management, 18(4), 36-46. https:// doi.org/10.2307/3665795

Dahlia, L., \& Siregar, V. . (2008). Pengaruh Coporate Social Responsibility terhadap Kinerja Perusahaan (Studi Empiris pada Perusahaan yang Tercatat di Bursa Efek Indonesia pada Tahun 2005 dan 2006). Jurnal Dan Prosiding SNA - Simposium Nasional Akuntansi, 9.

Edison, A. (2017). Struktur Kepemilikan Asing, Kepemilikan Institusional Dan Kepemilikan Manajerial Pengaruhnya Terhadap Luas Pengungkapan Corporate Social Responsibility (Csr). Jurnal Bisnis Dan Manajemen, 11(2), 164-175. https://doi.org/10.19184/ bisma.v11i2.6311

Faisal. (2005). Analisis Agency Costs, Struktur Kepemilikan dan Mekanisme Corporate Governance. Jurnal Riset Akuntansi Indonesia, 8(2), 175-190.

Fauzi, H., \& Sebelas, U. (2008). Corporate Social and Environmental Performance: A Comparative Study of Indonesian Companies ... Journal of Knowledge Globalization, 1(1), 81-105.

Greening, D. W., \& Turban, D. B. (1997). Corporate Social Performance and Organizational Attractiveness to Prospective Employees. Proceedings of the International Association for Business and Society, 40(3), 658-672. https://doi.org/10.5840/iabsproc1996746

Hackston, D., \& Milne, M. J. (1996). Some determinants of social and environmental disclosures in New Zealand companies. Accounting, Auditing $\mathcal{E}$ Accountability Journal, 9(1), 77-108. https://doi.org/10.1108/09513579610109987

Hadi, N. (2002). Faktor2 Yg Mempengaruhi Pengungkapan Laporan Tahunan.Pdf. Jurnal Maksi, 1, 39-61.

Huafang, X. (2007). Ownership Structure, Board Composition and Corporate Evidence from Listed Companies in China. Managerial Auditing Journal, 22(6), 1-3. https://doi.org/10.1108/02686900710759406

Indonesia, F. C. G. (2002). Corporate Governance: Tata Kelola Perusahaan. Jakarta.

Jensen, M. C., \& Meckling, W. H. (1976). Theory of The Firm: Managerial Behavior Agency Costs and Ownership Structure. Journal of Financial Economics, 3, 305-360. https://doi.org/10.1016/0304-405X(76)90026-X

Machmud, N., \& Djakman, C. D. (2008). Pengaruh Struktur Kepemilikan terhadap Keputusan Keuangan dan Nilai Perusahaan Survey pada Perusahaan Manufaktur di PT Bursa EFek Indonesia. Jurnal Dan Prosiding SNA - Simposium Nasional Akuntansi, 11.

Mahoney, L., \& Roberts, R. W. (2007). Corporate Social Performance, Financial Performance and Institutional Ownership in Canadian Firms. Accounting Forum, 31(3), 233-253. https:/ / doi.org/10.1016/j.accfor.2007.05.001

Mathews, M. . (1995). Social and Environmental Accounting: A Practical Demonstration of Ethical Concern? M . R . Mathews. Journal of Business Ethics, 14(8), 663-671.

Matoussi, H., \& Chakroun, R. (2008). “Board Composition, ownership Structure and Voluntary Disclosure in Annual Reports: Evidence from Tunisia". Laboratoire Interdisciplinaire de Gestion Universite- Enterprise (LIGUE). Labarotoire Interdisciplinaire de Gestion Université-Enterprise (LIGUE)., 
(January).

Morck, R., Shleifer, A., \& Vishny, R. W. (1988). Management Ownership and Market Valuation: An Empirical Analysis. Journal of Financial Economics, 20, 293-315.

Mursalim. (2007). Simultanitas Aktivisme Institutional, Struktur Kepemilikan, Kebijakan Deviden dan Hutang dalam Mengurangi Konflik Keagenan. Jurnal Dan Prosiding SNA - Simposium Nasional Akuntansi.

Noormala Dewi, S. (2015). Pengaruh Karakteristik Perusahaan Terhadap Pengungkapan Corporate Social Responsibility (CSR). BISNIS : Jurnal Bisnis Dan Manajemen Islam, 3(2), 364-393. https:/ / doi.org/10.21043/ bisnis.v3i2.1509

Permanasari, W. I. (2010). Pengaruh Kepemilikan Manajemen, Kepemilikan Institusional, dan Corporate Social Responsibility terhadap Nilai Perusahaan. Skripsi. Sarjana Jurusan Akuntansi Fakultas Ekonomi Universitas Diponegoro.

Prakasa, S., \& Astika, I. B. P. (2017). Pengaruh Leverage, Profitabilitas, dan Kepemilikan Manajemen Pada Corporate Social Responsibility Disclosure Perusahaan Pertambangan. E-Jurnal Akuntansi Universitas Udayana, 18(1), 189-215.

Puspitasari, A. D. (2009). Faktor-faktor yang Mempengaruhi Pengungkapan Corporate Social Responsilibily (CSR) pada Laporan Tahunan Perusahaan di Indonesia. Tesis. Magister Jurusan Akuntansi Fakultas Ekonomi Universitas Diponegoro.

Rahayu, R. N. (2015). Pengaruh Struktur Kepemilikan Asing, Kepemilikan Institusional dan Kepemilikan Manajerial terhadap Luas Pengungkapan Corporate Social Responsibility (CSR). Skripsi. Sarjana Jurusan Akuntansi Fakultas Ekonomi Universitas Widyatama.

Rawi, \& Muchlish, M. (2010). Kepemilikan Manajemen, Kepemilikan Institusi, Leverage dan Corporate Social Responsibility. Jurnal Dan Prosiding SNA Simposium Nasional Akuntansi, 13, 1-2.

Reni, F., \& Anggraini, R. (2006). Pengungkapan Informasi Sosial dan FaktorFaktor yang Mempengaruhi Pengungkapan Informasi Sosial dalam Laporan Keuangan Tahunan ( Studi Empiris pada Perusahaan-Perusahaan yang terdaftar Bursa Efek Jakarta ). Simposium Nasional Akuntansi IX Padang, 24, 121.

Rizky, Z., \& Yuyetta, E. N. A. (2015). Pengaruh Kepemilikan Manajerial, Kepemilikan Pemerintah, Konsentrasi Kepemilikan, Ukuran Pemerintah, Daya Saing Industri, serta Profitabilitas Perusahaan terhadap Luas Pengungkapan Corporate Social Responsibility. Diponegoro Journal of Accounting, 4(1), 1-10.

Rob, Gray; Kouhy, Reza; Lavers, S. (1995). Corporate Social and Environmental Reporting: A Review of The Literature and Longitudinal Study of UK Disclosure. Accounting, Auditing \& Accountability Journal, 8(2), 47-77.

Rohmah, D. (2015). Faktor-Faktor yang Mempengaruhi Pengungkapan Corporate Social Responsibility di Dalam Laporan Sustainability. Jurnal Bisnis Dan Manajemen, 5(2), 243-262. https:/ / doi.org/10.15408/ess.v5i2.2347 Roshima, S., Yuserrie, H. Z., \& Hasnah, H. (2009). The relationship between 
corporate social responsibility disclosure and corporate governance characteristics in Malaysian public listed companies. Social Responsibility Journal, 5(2), 212-226. https:/ / doi.org/10.1108/17471110910964496

Rustendi, T., \& Jimmi, F. (2008). Pengaruh Hutang dan Kepemilikan Manajerial Terhadap Nilai Perusahaan Pada Perusahaan Manufaktur. Jurnal Akuntansi FE Unsil, 3(1), 411-422.

Sartono, R. A. (2010). Manajemen Keuangan. Yogyakarta: BPFE.

Siallagan, H., \& Machfoedz, M. (2006). Mekanisme Corporate Governance, Kualitas Laba Dan Nilai Perusahaan. Simposium Nasional Akuntansi 9 Padang, 13, 1-23.

Sissandhy, A. K., \& Sudarno. (2014). Pengaruh Kepemilikan Asing Terhadap Nilai Perusahaan dengan Pengungkapan Corporate Social Responsibility Sebagai Variabel Intervening. Diponegoro Journal Of Accounting, 3(2), 1-7.

Suhardjanto, D., \& Nugraheni, S. (2012). Pengaruh Corporate Social Responsibility Dan Leverage Terhadap Nilai Perusahaan. Jurnal Akuntansitansi, 16(2), 162-175. https://doi.org/10.30596/intiqad.v9i2.1385

Suparjan, A., \& Mulya, A. S. (2012). Pengaruh Kinerja Sosial dan Kinerja Keuangan Perusahaan dengan Pengungkapan Corporate Social Responsibility (CSR) Sebagai Variabel Intervening terhadap Nilai Perusahaan. Media Riset Akuntansi, Auditing \& Informasi, 12(3), 27-59.

Waddock, S. A., \& Graves, S. B. (1997). The Corporate Social PerformanceFinancial Performance Link: Evidence from France. Strategic Management Journal, 18(4), 303-319. https:/ / doi.org/10.2139/ssrn.306599

Wahidawati. (2002). Pengaruh Kepemilikan Manajerial dan Kepemilikan Institusional Terhadap Kebijakan Hutang Perusahaan: Sebuah Perspektif Agency Theory. Jurnal Riset Akuntansi Indonesia, 5(1), 86-102.

Wahyudi, I., \& Busya, A. (2008). Corporate Social Responsibility: Prinsip Pengaturan dan Implementasi. Malang: In-Trans Publishing.

Wakidi, R. H., \& Siregar, H. S. (2011). Pengaruh Sisi Internal Dan Eksternal Perusahaan terhadap Pengungkapan Tanggung Jawab Sosial pada Perusahaan Manufaktur yang Terdaftar di BEI. Jurnal Ekonom, 14(4), 180190.

Wati, K. M. (2012). Simultanitas Struktur Kepemilikan, Kebijakan Dividen, dan Utang. Jurnal Riset Akuntansi, 8(2), 159-173.

WCBSD. (2011). CSR: Meeting Changing Expectations.

Wulandari, A. A. A. I., \& Sudana, I. P. (2018). Pengaruh Profitabilitas, Kepemilikan Asing, Kepemilikan Manajemen, dan Leverage pada Intensitas Pengungkapan Corporate Social Responsibility. E-Journal Akuntansi Universitas Udayana, 22(2), 1445-1472.

Yoantha, U. (2015). Akibat Hukum Pembelian Saham Perusahaan Bukan Penanaman Modal Asing oleh Warga Negara Asing atau Badan Hukum Asing. USU Law Journal, 3(1), 156-166. 